\title{
The Impact of Hydraulic Fracturing on Groundwater Quality in the Permian Basin, West Texas, USA
}

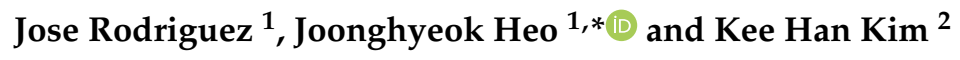 \\ 1 Department of Geosciences, University of Texas-Permian Basin, Odessa, TX 79762, USA; \\ rodriguez_j94633@utpb.edu \\ 2 Department of Architectural Engineering, University of Ulsan, Ulsan 44610, Korea; keehankim@ulsan.ac.kr \\ * Correspondence: heo_j@utpb.edu
}

Received: 22 December 2019; Accepted: 1 March 2020; Published: 12 March 2020

\begin{abstract}
The purpose of this study is to evaluate the impact of hydraulic fracturing on groundwater quality in Ector, Midland, and Martin Counties located in the Permian Basin, West Texas. Chemical fluids used in hydraulic fracturing and groundwater quality parameters (chloride, fluoride, calcium carbonate, nitrate, $\mathrm{pH}$, and total dissolved solids), were statistically analyzed assuming a normal probability function distribution and through a one-way analysis of variance of the parameters. Additionally, the depth of groundwater well versus water quality analysis as well as historical analysis of groundwater quality parameters of wells were performed. The result for each county was individually examined and contrasted with the other two counties, in order to make inferences about groundwater quality and oil and gas activities for the three counties. Potential risks to human health from the abnormal levels of the groundwater quality parameters studied were also discussed based on the Environmental Protection Agency's (EPA) standards. This research provides important information on groundwater quality in the Permian Basin and contributes on understanding the response to development in hydraulic fracturing.
\end{abstract}

Keywords: hydraulic fracturing; Permian Basin; West Texas; groundwater quality; chemical fluid; total dissolved solids (TDS); nitrate; chloride

\section{Introduction}

Groundwater in the United States is most commonly used for public water supply, and is the largest source of usable water, even more so than all of the county's lakes combined (including the Great Lakes). Groundwater is also used for the main water supply in the United States since it is much more difficult to pollute than surface water, but when the groundwater is polluted it is harder to clean as well [1]. Considering the vast reliance on water for a multitude of living functions (human consumption, agricultural growth/irrigation, livestock consumption, and indoor purposes such as bathing etc.) it is imperative to keep water clean to protect the environment, ecosystems, and humans [1].

Pollution in groundwater has two sources. It is either caused by human activities, or it can happen naturally. A large number of human practices, like agriculture, industrialization, and mining can seriously affect groundwater quality. Located in West Texas, the main economic activity in the Permian Basin of the United States is oil and gas production [2]. This statement is also true for Midland, Martin, and Ector counties, which are located above some of the best oil and gas reservoirs in the Permian Basin [2].

As an active producer of hydrocarbon for more than a century, wells in the Permian Basin had produced more than 33.4 billion barrels of oil by September 2018. Its oil production represents a fifth of the total production of the country, and its reserves are estimated to be over five billion barrels of oil, consolidating this region of West Texas as one of the top producers in the United States and the 
world [3]. Due to its privileged location during the Paleozoic, the rocks layer formed in what are now Midland, Martin, and Ector counties, and became a store of organic matter. Organic matter deposited during the Paleozoic turned into hydrocarbons that were stored in reservoir rock due to geological processes [3]. The lack of porosity and permeability of reservoir rocks complicated the extraction of hydrocarbons for decades, until the incorporation of new technologies in the 2010s [4].

There are different techniques that have been helping oil and gas production through the years. But hydraulic fracturing has been the one that has most benefited the oil and gas economy in West Texas [5]. It enhances oil and gas production by creating fractures through the injection of a pressurized mixture of fluids in non-porous rock reservoirs [6]. As a relatively newer technique, the effects of hydraulic fracturing on groundwater quality are still being studied and are not totally understood. There has been speculation that hydraulic fracturing can cause pollution to groundwater aquifers $[7,8]$. Various States, like California, Wisconsin, Ohio, Minnesota, Pennsylvania, Arkansas, and Colorado have had studies discussing the changes to groundwater quality since hydraulic fracturing had been introduced to each area. Long (2014) studied some challenges for groundwater quality from the hydraulic fracturing industry in the States of Wisconsin and Minnesota. Even though it is challenging to determine the impact of oil and gas activities to groundwater aquifers, there is evidence that important parameters like $\mathrm{pH}$ and salinity are affected [9]. Therefore, major ions of chloride $(\mathrm{Cl})$ should be monitored to ensure groundwater quality. In 2016, EPA also mentioned that levels of total dissolved solids (TDS) can be affected by hydraulic fracturing practices [10].

Fluoride $(\mathrm{F})$ and nitrates $\left(\mathrm{NO}_{3}\right)$ levels have also proven to be affected by oil and gas activities. Even though there has not been an extensive study to examine the relationship between these contaminants and hydraulic fracturing in depth, Marcus and Bonds (1999) analyzed the effects of hydraulic fracturing sand and contamination in aquifers of different depths. They determined that fluoride levels stayed close to their original values until the deeper depths of the aquifer, where those levels had increased, and nitrate levels had decreased [11]. The cause behind the decrease in nitrate levels was explained by reductive dehalogenation and metallic reduction reactions from the iron foam proppants. Not every well uses iron foam proppants to open fractures, which would explain any differences in values collected from each research. Shales have trace elements, such as arsenic, that are making up for the arsenic level naturally occurring in the groundwater [11].

Studies conducted by Hildenbrand et al. (2015) analyzed the connection between hydraulic fracturing and groundwater pollution after analyzing samples collected aquifers in Texas [12]. Although not a definitive connection between oil and gas activities and groundwater contamination, the finding of several different organic and inorganic compounds by Hildenbrand incentivizes further study on the topic. More recent studies conducted by Hildenbrand et al. (2016), this time in the Permian Basin, provided more evidence of groundwater quality and Hydraulic Fracturing [12]. Hildebrand's temporal variation in groundwater quality found significant changes in Total Organic Carbon (TOC) and $\mathrm{pH}$ levels in groundwater in the 13 months of the study. In parallel, Backstrom (2018) has been analyzing the connection between oil and gas activities and groundwater pollution in the Permian Basin [13]. His descriptive analysis evidences that oil and gas operators are less likely to show detailed information about well stimulation where groundwater management plans exist. Backstrom also found that less information was found when volumes of hydraulic fluids used were higher. Backstrom's findings raise concerns about a well-known relation between groundwater quality and hydraulic fracturing by some oil and gas operators.

Since there has been scientific evidences about the negative consequences of oil and gas production on groundwater reservoirs, an extensive study in the Permian Basin, where oil and gas production are prominent, as well as where groundwater resources are vital for the economy and health of their inhabitants, is imperative. Therefore, the objective of this study is to determine the impact of hydraulic fracturing to the groundwater quality in Ector County, Midland County, and Martin County. 


\section{Study Area}

The study area is the counties of Ector, Midland, and Martin (Figure 1), which are located in the Permian Basin of the United States of America. The area of the three counties extends 2720 square miles in total. With an annual average precipitation between 10 and 20 inches a year, the climate in West Texas can be and categorized as semi-arid [14]. Precipitation is scarce, temperatures during late spring, summer, and early fall are high, and strong winds are common. The arid soil surface is formed mainly by lime and calcium carbonate [15]. According to the weather station located in The Midland International Airport, in 2016, the region presented a total annual precipitation of 8.78 inches. Most of this precipitation was in the form of thundershowers during the months of May and October (Figure 2). West Texas' low precipitation level contributes to the lack of significant water bodies, making the utilization of groundwater, and its quality, vital for the area.

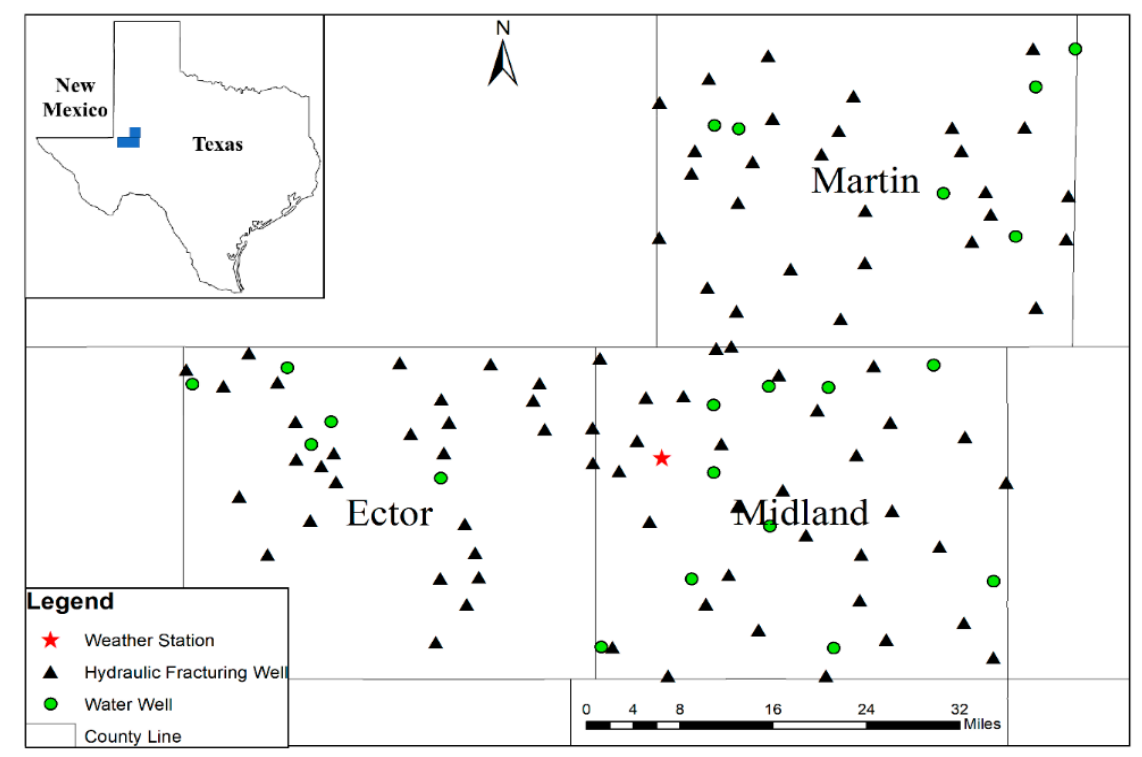

Figure 1. Location of wells and weather station in the study area: Ector County, Midland County, and Martin County.
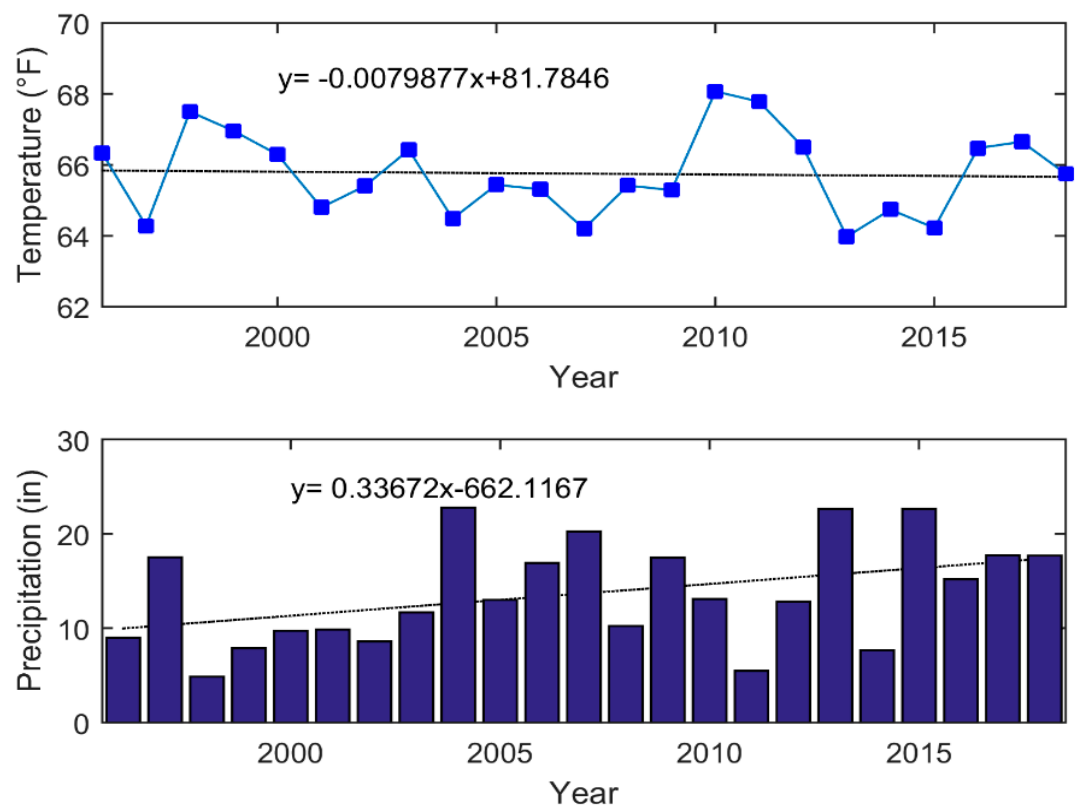

Figure 2. Annual average temperature and annual total precipitation reported by the Midland International Airport Station in the study area. 
In the Permian Basin, the average depth of groundwater varies between 100 and $200 \mathrm{ft}$ [16]. Due to their slow recharge rate, aquifers located in arid and semiarid areas are the most susceptible to contamination by natural processes and pollution by human activities [17]. The three main aquifers that provide groundwater to Ector, Midland, and Martin counties are the Edwards-Trinity Plateau, the Pecos Valley, and the Ogallala [18]. With the population increasing more than $15 \%$ in the three counties since $2008[19,20]$, the principal economic activities are oil and gas production. Beginning in the early twentieth century, the hydrocarbon production in the Permian Basin has being escalating since the application of new technologies for the production of non-conventional reservoirs [4]. Starting to be widely used in the 2010s, the most remarkable of these technologies is hydraulic fracturing. In 2016, Ector, Midland, and Martin counties registered 85, 494, and 195 hydraulic fracturing jobs, respectively [21]. These numbers helped to consolidate the region as one of the top producers in the world [4].

Groundwater originating from within the study area is captured from four aquifers: Ogallala (major), Pecos Valley (major), Edwards-Trinity Plateau (major), and Dockum (minor) [18]. The Ogallala aquifer is the largest aquifer in the United States and is a major aquifer of Texas, underlying much of the High Plains region. It consists of sand, gravel, clay, and silt and has a maximum thickness of $800 \mathrm{ft}$. The Pecos Valley aquifer is one of major aquifer in West Texas. Water bearing sediments include alluvial and windblown deposits in the Pecos River Valley. The Edwards-Trinity Plateau aquifer is a major aquifer extending across much of the southwestern part of the state. Water quality ranges from fresh to slightly saline, and most of the groundwater is used for irrigation, municipal supplies, industrial use, and power generation. The Dockum aquifer is a minor aquifer found in the northwest part of the state. It is a sandstone aquifer and the basal member of the Dockum formation with the upper layers being predominantly siltstone and claystone.

The aquifers are a valuable source of water for ranchers, farmers, and the recovery of oil and gas in the region. The deepest groundwater well is within the Dockum at $1600 \mathrm{ft}$ and the Ogallala contains the shallowest well at $70 \mathrm{ft}$. Average recharge of the aquifer is calculated to be 30,000 acre-feet per year and occurs primarily through infiltration of precipitation. Due to the high rate of evaporation in this arid region, very little reaches the water table. The recharge rate of this aquifer is lower than the depletion rate with variations from state to state. The study area in the Permian Basin is currently experiencing the highest depletion rate, whereas certain areas have seen a drawdown of as much as $100 \mathrm{ft}$ [16]. Hydraulic characteristics that influence the effectiveness of an aquifer include transmissivity and storage coefficient. Average values for these characteristics are 365 square feet per day for transmissivity and 0.074 for storage coefficient [18]. Lateral movement of ground water from the Ogallala to the Trinity aquifer likely occurs along the northern edge of the region where the two formations abut. Hydraulic fracturing is also well known for its possible effects on groundwater reservoirs. During hydraulic fracturing, different chemicals are injected underground in order to create fractures and enhance the production of hydrocarbons in reservoirs with low porosity and permeability [22]. Even though the average oil and gas well depth in the Permian Basin varies between 5000 and 15,000 ft [3], studies show that infiltrations from fracturing jobs can affect groundwater bodies shallower than $1000 \mathrm{ft}$ [12].

To develop a better understanding of the effect of hydraulic fracturing on groundwater quality in Ector, Midland, and Martin counties, information from 774 wells were analyzed from FracFocus [23]. It contains extensive information about 85 oil and gas wells in Ector county, 494 in Midland county, and 195 in Martin county. We collected all historically available data in the study area and checked the location of their wells. To understand the distribution of chemical fluids, the wells must be uniformly distributed throughout the study area. For this reason, we finalized the 30 wells per county to create an even distribution throughout the study area (Figure 1). The data on selected parameters were required to provide long-term data with a relatively dense observation network. Each well was mapped within the study area using its provided latitude/longitude coordinate and contaminant concentration level. In parallel, information provided by the Texas Water Development Board (TWDB) about groundwater 
wells located and studied in the study area in 2016 was analyzed [24]. The dataset provided extensive information about water quality of 21 samples taken from five wells located in Ector County, 10 wells located in Midland County, and six wells located in Martin County (Table 1).

Table 1. Groundwater well numbers, locations, and depths (depth unit: ft. below land surface).

\begin{tabular}{ccccc}
\hline & Well Number & Latitude & Longitude & Well Depth \\
\hline \multirow{4}{*}{ Ector County } & 2759503 & 32.0598611 & -102.6697389 & 100 \\
& 4503301 & 31.9594444 & -102.6400000 & 120 \\
& 4504120 & 31.9888889 & -102.6152778 & 170 \\
& 4505705 & 31.9151944 & -102.4789167 & 140 \\
& 2758902 & 32.0383340 & -102.7875000 & 140 \\
& & Average depth & 134 \\
\hline \multirow{4}{*}{ Midland County } & 2858402 & 32.0635778 & -101.8672833 & 77 \\
& 2763901 & 32.0110306 & -102.1407194 & 90 \\
& 2764804 & 32.0358340 & -102.0719440 & 150 \\
& 4557703 & 32.0341670 & -101.9980560 & 70 \\
& 4522604 & 31.9225000 & -102.1402780 & 89 \\
& 4516208 & 31.6936940 & -102.2800440 & 225 \\
& 4515801 & 31.8526690 & -102.0708250 & 131 \\
& 4417410 & 31.6922220 & -102.1674170 & 170 \\
& 4410809 & 31.7796610 & -101.9911110 & 250 \\
& & Average depth & 160 \\
& 2850301 & 32.2322220 & -101.7655560 & 39 \\
& 2835205 & 32.4783330 & -101.6916670 & N/A \\
& 2748106 & 32.3738890 & -102.1091670 & 218 \\
& 2739901 & 32.3776389 & -102.1391944 & 214 \\
& 2842705 & 32.2888890 & -101.8552780 & 122 \\
& 2835401 & 32.4283330 & -101.7402780 & 30 \\
& & Average depth & 125 \\
\hline
\end{tabular}

\section{Materials and Methods}

\subsection{Hydraulic Fracturing Information}

For the 90 hydraulic fracturing wells chosen, the concentration of each substance used in each fluid mixture was extracted from the dataset, for the purpose of knowing which ones where the most commonly used in the area and likely to affect groundwater reservoirs. Additionally, the group mean $(\bar{X})$, and standard deviation $(\delta)$ of the concentration of the most representative substances in the three groups of 30 wells were calculated. 95\% confidence intervals for the population means were calculated Equation (1), assuming a normal probability distribution function, due to the relevant size of each group [25].

$$
\bar{X} \pm Z_{\propto / 2} \frac{\delta}{\sqrt{n}}
$$

where $n=$ Sample size; $Z_{\propto / 2}=$ Confidence coefficient for the confidence level.

\subsection{Groundwater Quality Analysis}

Levels of arsenic (As), fluoride $\left(\mathrm{F}^{-}\right)$, chloride $\left(\mathrm{Cl}^{-}\right)$, calcium carbonate $\left(\mathrm{CaCO}_{3}\right)$, nitrate $\left(\mathrm{NO}_{3}\right)$, $\mathrm{pH}$ and total dissolved solids (TDS) were collected from the TWDB dataset, since all of them are relevant water quality parameters that had proven to be affected by unconventional production of hydrocarbons in previous studies [5,26-28], and abnormal concentrations of them in water can lead to serious effects to human health and the environment [29]. For this study, the mean and standard deviation for the concentrations of each water parameter per county was calculated. In order to make statistical deductions due to the little information provided by the literature, a one-way analysis of 
variance (ANOVA) was performed. This analysis calculates an $F_{0}$ value per each group of water parameters Equation (2), in which a critical value $\mathrm{F}^{C V}$ with 2 and 11 degrees of freedom from an F-distribution is calculated, in order to determine the probability that the means of the level of water parameters, per county, will be statistically different to the rest [30].

$$
F_{0}=\frac{M S T R}{M S E}
$$

where $M S T R=$ mean square treatment; $M S E=$ mean square error.

Additionally, the concentration of $\mathrm{As}, \mathrm{Cl}^{-}, \mathrm{F}^{-}, \mathrm{CaCO}_{3}, \mathrm{NO}_{3}$, TDS, and the level of $\mathrm{pH}$ vs depth of groundwater well, for the 22 wells previously mentioned, were graphed. The linear regression relation between depth and concentration of each groundwater parameter was also calculated in Equation (3) and graphed [31].

$$
y=A_{0}+A_{1} \mathrm{x}+c
$$

where $A_{0}=$ population y intercept; $A_{1}=$ population slope coefficient; $c=$ random error term.

Finally, the levels of $\mathrm{As}, \mathrm{Cl}^{-}, \mathrm{F}^{-}, \mathrm{CaCO}_{3}, \mathrm{NO}_{3}$, TDS, and $\mathrm{pH}$ located in each county were also analyzed. With the intention of getting a better notion of the variation of the groundwater parameter overtime, a cubic Hermite interpolation Equation (4) was used, since it has proven to be an efficient technique to model changes of groundwater parameters in groundwater [32-34].

$$
f(t)=a t^{3}+b t^{2}+c t+d
$$

where:

$$
\begin{gathered}
a=\frac{-f\left(t_{1}\right)+3 f\left(t_{2}\right)-3 f\left(t_{3}\right)+f\left(t_{4}\right)}{2} \\
b=f\left(t_{1}\right)-\frac{5 f\left(t_{2}\right)}{2}+2 f\left(t_{3}\right)-\frac{f\left(t_{4}\right)}{2} \\
c=\frac{-f\left(t_{1}\right)+f\left(t_{3}\right)}{2} \\
d=f\left(t_{2}\right)
\end{gathered}
$$

and:

$$
\mathrm{t}_{1}<\mathrm{t}_{2}<\mathrm{t}_{3}<\mathrm{t}_{4}
$$

\section{Results and Discussion}

\subsection{Hydraulic Fracturing}

Table 2 summarizes the information obtained after analyzing the FracFocus hydraulic fracturing wells database [23]. It presents the concentrations of the most common substances found in the 30 wells chosen per each county. Similarly, Figure 3 graphically shows the concentration of each substance in relation with the rest of the mixture used for hydraulic fracturing purposes. This analysis led to the identification of the five main substances used in the hydraulic fracturing fluid of the three counties. Table 2 also shows the statistical analysis performed to each of the main five substances found in the 90 hydraulic fractured fluid logs scrutinized. This statistical analysis led to the determination of the $95 \%$ confidence intervals for the mean of each of the substances. Figure 4 shows a graphical comparison of the confidence intervals of each substance per county. 
Table 2. Statistical analysis of chemical fluids used in hydraulic fracturing in Ector County, Midland County, and Martin County.

\begin{tabular}{ccccccc}
\hline & Water $\left.\mathbf{( H}_{\mathbf{2}} \mathbf{O}\right)$ & $\begin{array}{c}\text { Quartz and } \\
\text { Sand }\left(\mathrm{SiO}_{2}\right)\end{array}$ & $\begin{array}{c}\text { Petroleum } \\
\text { Distillate }\end{array}$ & Guar Gum & $\begin{array}{c}\text { Hydrochloric } \\
\text { Acid (HCl) }\end{array}$ \\
\hline Ector County & \%Total & $83.05 \%$ & $15.61 \%$ & $0.18 \%$ & $0.19 \%$ & $0.38 \%$ \\
Midland & \%Total & 83.05 & 15.61 & 0.18 & 0.19 & 0.38 \\
County & $\mathrm{X}$ & $90.24 \%$ & $9.41 \%$ & $0.03 \%$ & $0.05 \%$ & $0.10 \%$ \\
Martin & \%Total & $84.15 \%$ & $14.39 \%$ & 0.03 & 0.05 & 0.10 \\
County & $\mathrm{X}$ & 84.15 & 14.39 & 0.09 & $0.05 \%$ & $0.93 \%$ \\
\hline
\end{tabular}

Ector County

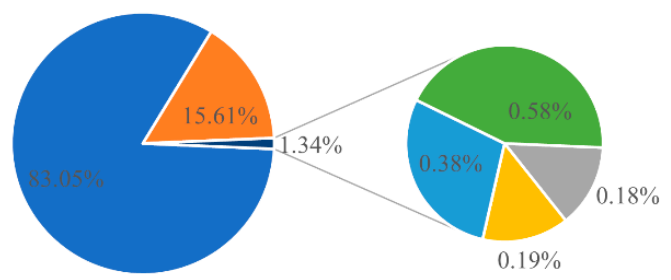

- Water (H2O)

- Guar Gum

Martin County

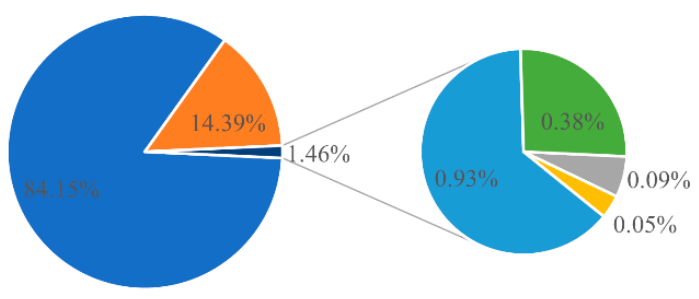

- Quartz and Sand (SiO2) = Petroleum Distillate

- Hydroloric Acid $(\mathrm{HCl}) \quad$ - Other

Figure 3. Amounts of chemical fluids used in hydraulic fracturing in Ector County, Midland County, and Martin County.
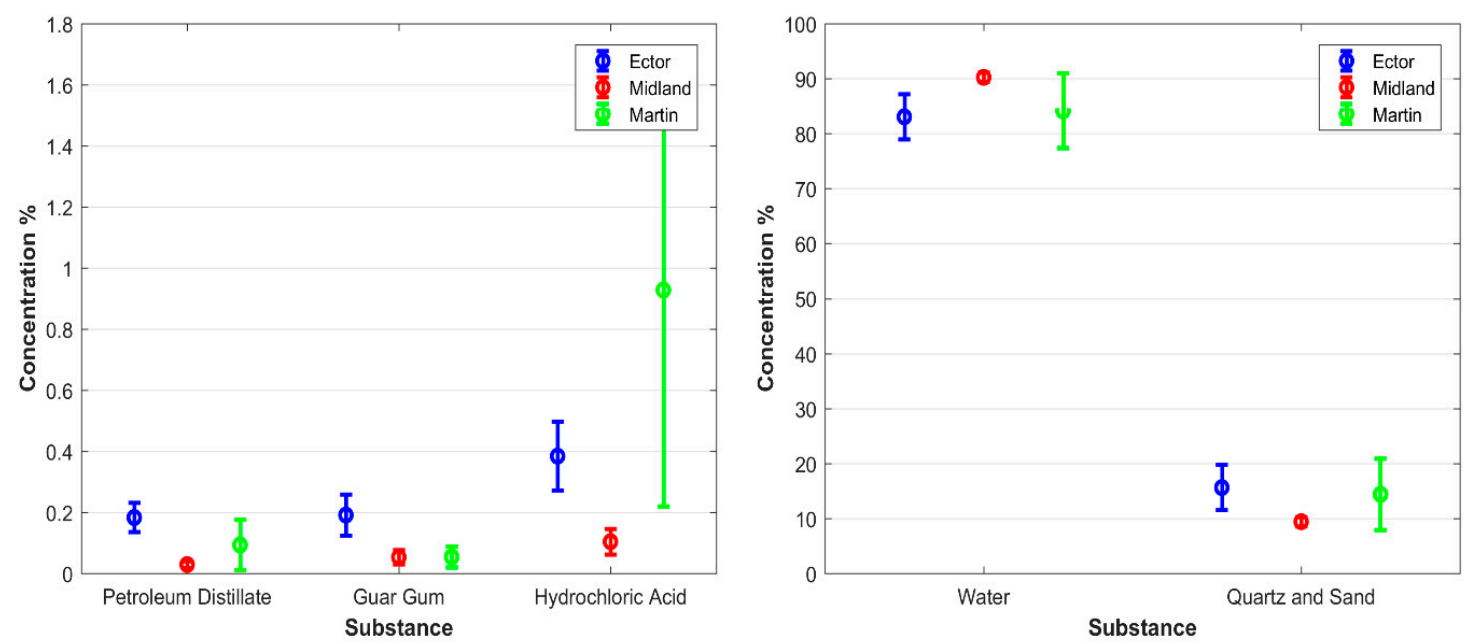

Figure 4. Confidence intervals of chemical fluids used in hydraulic fracturing in Ector County, Midland County, and Martin County. 
Hydraulic fracturing fluids compositions vary depending the zone where the procedure is performed [6]. While water and sand were the substances with the highest concentrations, the most common pollutants found in the hydraulic fracturing fluid database for the study area were guar gum, petroleum distillate, and hydrochloric acid. Even though the three counties are located next to the others, and the characteristics of oil and gas reservoirs are alike [35], considerable variations in the concentration of chemicals used for hydraulic fractured were observed.

Hydrochloric acid $(\mathrm{HCl})$, a strong inorganic acid, is used because of its corrosive properties to remove cement particles present in the well from previous drilling stages and enhance the fracturing process [36]. $\mathrm{HCl}$ is extremely toxic to human health. Ingestion, as well as contact with body parts, can develop serious complications that might end in death [37]. Therefore, the presence of this dangerous chemical near water bodies that are used for human consumption represents an imminent risk. Concentrations of $\mathrm{HCl}$ proved to be much higher in Martin and Ector counties. Due to the wideness of the confidence intervals for the mean of the concentration of $\mathrm{HCl}$ for Martin County, compared to results for Midland and Martin counties, it is possible that the oil and gas wells chosen in Martin County for the purposes of the study were not statistically representative of the entire regional population of samples (Figure 4). However, since the value of the mean obtained for Martin County is more than twice the mean obtained for the county with the closed $\mathrm{HCl}$ concentration, it is possible to say that the hydraulic fracturing fluid used in Martin County during 2016 had a much higher concentration of $\mathrm{HCl}$ that the one in the other two counties.

Synthetized from a small bean named guar, guar gum is an organic substance used to increase the viscosity of hydraulic fracturing fluids, which makes hydraulic fracturing more effective by improving the results of the pressure pumping of fluids to the fractures made to the reservoir rocks [38]. Even though some allergic reactions have been associates with the ingestion of guar gum, no serious consequences to human health, nor environmental pollution hazards have been attributed to guar gum [39]. Ector County hydraulic fracturing wells presented the highest levels of guar gum. This can be explained, since Ector County hydraulic fracturing wells also presented overall highest concentration of sand. The viscosity of the hydraulic fracturing fluid is also important to suspend grains of sands to be carried more efficiently into the fractures [38]. When the content of sand for the fluid increases, the amount of guar gum used consequently increases.

Light petroleum distillates used in hydraulic fracturing fluids are often derivatives of diesel. They are friction reducers for the hydraulic fracturing fluids [40]. Petroleum distillates can contain toxic chemicals like benzene, toluene, ethylbenzene, and xylene. All of these chemicals have proven to be highly toxic for human consumption and be related with groundwater pollution through infiltration into groundwater reservoirs [41]. Ranging from $0.13 \%$ to $0.23 \%$, Ector County presented the highest concentration of petroleum distillates in the hydraulic fracturing fluid (Figure 4). This result can be explained again by the high concentration of sand used in Ector County's hydraulic fracturing fluid. Since petroleum distillates are used to reduce the friction produced by the passing of the fluid through the pipe system, a thicker substance that contains more grains of sand demands higher levels of friction reducers. Friction from the fluid can create extra pressure on surface that would affect the required pump rate during the process [40].

\subsection{Groundwater Quality}

Arsenic (As) is a toxic metalloid chemical element found in water, soil, and air. It is a naturally-occurring substance in groundwater that can be found in igneous and sedimentary rocks. Fluoride $\left(\mathrm{F}^{-}\right)$, the ionic form of Fluorine $(\mathrm{F})$, is an electronegative inorganic element that occurs naturally in drinking water. Nitrate $\left(\mathrm{NO}_{3}\right)$ is an inorganic polyatomic ion that is naturally occurring in the environment from the nitrogen cycle. Chloride $\left(\mathrm{Cl}^{-}\right)$, the ionic form of chloride (C), is an electronegative inorganic element, present both in fresh and saltwater, and commonly used in drilling mud. Calcium carbonate $\left(\mathrm{CaCO}_{3}\right)$ is a chemical compound that is commonly used in drilling fluids like chloride. $\mathrm{pH}$ is the measure of hydrogen concentration using a scale and it reveals how acidic or 
basic the water is. Total dissolved solids (TDS) is a parameter that counts the amount of organic and inorganic materials present in water, which includes ions, salts, metals, and minerals [42-45].

Table 3 shows the average of the seven different groundwater quality parameters associated with pollution by hydraulic fracturing and other oil and gas extraction techniques for the 14 groundwater logs scrutinized. This information led to the creation of a comparison box plot of the data per each county (Figure 5). Figure 5 provides information about the median, 25th and 75th percentiles, and extreme data present in each dataset by county, which shows the distribution and dispersion of the groundwater quality data acquired [46]. All of the above are done with the intention to investigate what county presented higher pollution levels in 2016, and how each group of groundwater parameter was distributed around the mean obtained.

Table 3. Statistical mean of groundwater quality parameter in Ector County, Midland County, and Martin County.

\begin{tabular}{lccccccc}
\hline & $\begin{array}{c}\mathrm{As} \\
(\mathbf{u g} / \mathrm{L})\end{array}$ & $\begin{array}{c}\mathrm{Cl}^{-} \\
(\mathbf{m g} / \mathbf{L})\end{array}$ & $\begin{array}{c}\mathbf{F}^{-} \\
(\mathbf{m g} / \mathbf{L})\end{array}$ & $\begin{array}{c}\mathrm{CaCO}_{3} \\
(\mathbf{m g} / \mathbf{L})\end{array}$ & $\begin{array}{c}\mathbf{N O}_{3} \\
(\mathbf{m g} / \mathbf{L})\end{array}$ & $\mathbf{p H}$ & $\begin{array}{c}\text { TDS } \\
(\mathbf{m g} / \mathbf{L})\end{array}$ \\
\hline Ector & 4.16 & 696.32 & 1.82 & 693.89 & 23.35 & 7.14 & 1726.90 \\
Midland & 20.76 & 529 & 2.25 & 981.96 & 0.89 & 7.02 & 2059.42 \\
Martin & 20.10 & 302.50 & 4.76 & 654.10 & 1.63 & 7.08 & 1178.99 \\
\hline
\end{tabular}
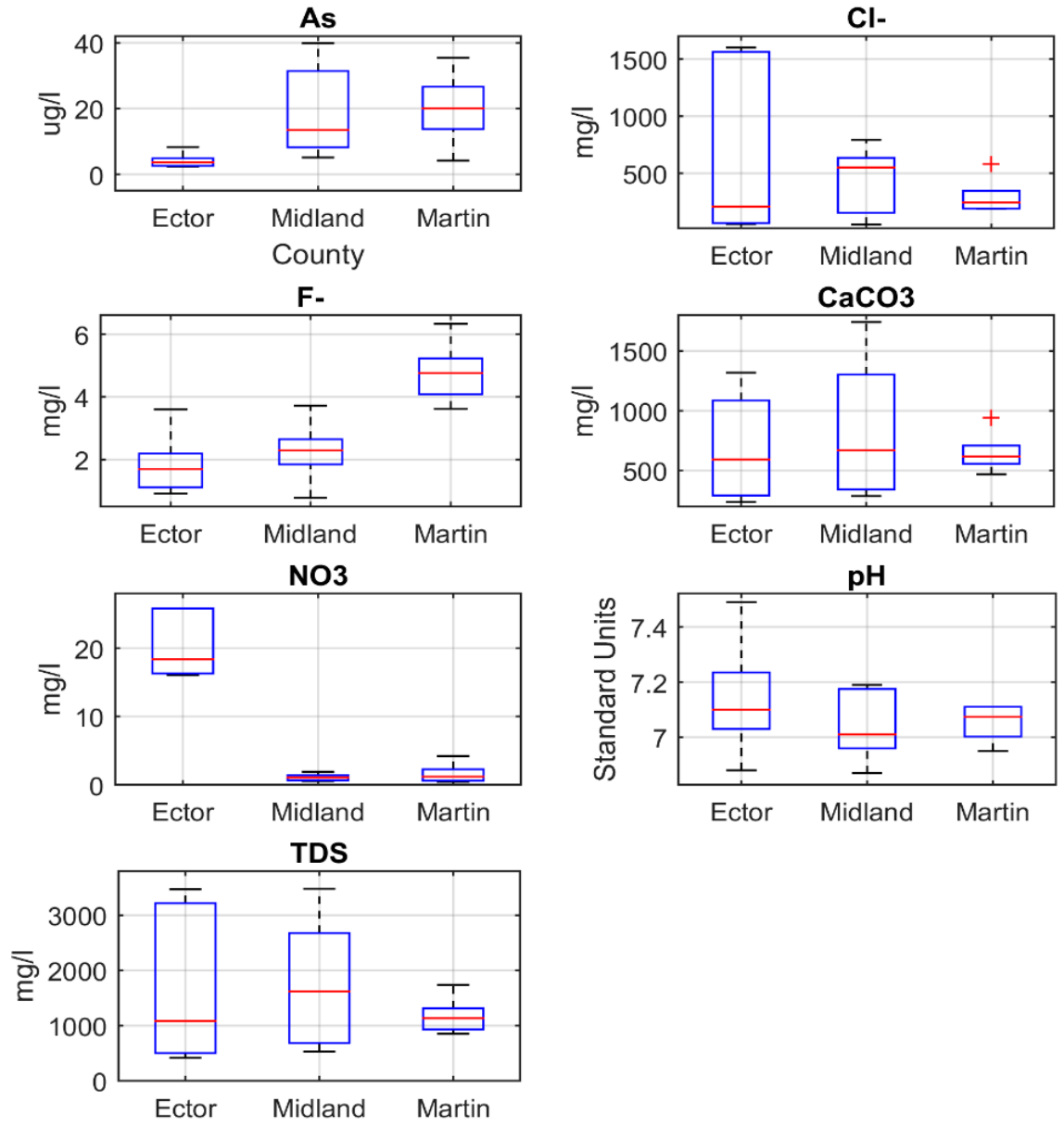

Figure 5. Box plots of groundwater quality parameter in Ector County, Midland County, and Martin County.

Through a One-Way Analysis of Variance, $F_{0}$ and the evaluation of $F_{0}$ in an F Cumulative Function Distribution (cdf) were calculated per each group of groundwater quality parameter (Table 4). cdf 
$\left(F_{0}\right)$ represents the percentage of the means of groundwater parameters per county to be different one another. The greater $\mathrm{cdf}\left(F_{0}\right)$, the higher the chances for at least one of the means to be different to the other two [30]. Even though, through box diagrams, we can appreciate the differences between groundwater parameters per county (Figure 5), the results from the One-Way Analysis of Variance reflected which of the groundwater parameters per county were relevantly worth mentioning as significantly dissimilar (Table 4). The means of As, $\mathrm{F}^{-}$, and $\mathrm{NO}_{3}$ per county have more than $90 \%$ chances of representing some difference between the counties. Although the One-Way Analysis of Variance resulted in less than 55\% chances for the rest of water quality parameters to be undoubtedly different one another, inferences from the mean and standard deviation per group can still be made (Table 3).

Table 4. One- way analysis of groundwater quality parameters in the study area.

\begin{tabular}{ccc}
\hline & $\boldsymbol{F}_{\mathbf{0}}$ & cdf $\left(\boldsymbol{F}_{\mathbf{0}}\right)$ \\
\hline $\mathrm{As}$ & 3.5 & $93.65 \%$ \\
$\mathrm{Cl}^{-}$ & 0.81 & $53.22 \%$ \\
$\mathrm{~F}^{-}$ & 11.81 & $99.85 \%$ \\
$\mathrm{CaCO}_{3}$ & 0.25 & $21.74 \%$ \\
$\mathrm{NO}_{3}$ & 13.13 & $99.9 \%$ \\
$\mathrm{pH}$ & 0.58 & $42.36 \%$ \\
$\mathrm{TDS}$ & 0.44 & $34.30 \%$ \\
\hline
\end{tabular}

$\mathrm{Cl}^{-}$level is the highest in Midland County, where the hydraulic fracturing activity outnumbered the other two counties for more than 2.5 times more in 2016. $\mathrm{Cl}^{-}$level is also related with the use of $\mathrm{HCl}$, since $\mathrm{Cl}^{-}$can be originated when $\mathrm{HCl}$ reacts with metals in water [47]. The variation of the $\mathrm{CaCO}_{3}$ per County (Figure 5) can be an evidence for the close relation of hard water, rich in inorganic minerals, with the formation of $\mathrm{Cl}^{-}$. The lowest average $\mathrm{pH}$ levels was observed in Midland and Martin counties (Figure 5), where hydraulic fracturing practices and consequent release of hydrochloric acid to the underground were the first and the second in numbers of hydraulic fracturing wells among the three counties [21]. $\mathrm{Cl}^{-}$in groundwater was also proven to be related to $\mathrm{CaCO}_{3}$ and TDS. Figure 5 shows a certain relationship between the three parameters. The fact that $\mathrm{CaCO}_{3}$ and $\mathrm{Cl}^{-}$are some of the main components of TDS can explain this correspondence [48]. In the same way, arsenic (As) level seemed to have a certain correlation, being the highest in Martin, and the lowest in Ector.

The higher hydraulic fracturing activity in Midland County and Martin County during 2016 can account for their higher levels of arsenic (As) and $\mathrm{F}^{-}$(Figure 5). Studies conducted in Barnett Shale region, Texas, mention that the vibrations produced by hydraulic fracturing can shake rust from pipe systems and transport arsenic (As) to groundwater aquifers [49]. Likewise, since arsenic is a natural occurring substance in rock deposits, fractures generated by hydraulic fracturing can transport arsenic-rich sediments to upper groundwater aquifers [50]. Since $\mathrm{HCl}$ is the main dissolvent agent used to produce fractures in oil and gas reservoirs [36], Martin County's highest $\mathrm{HCl}$ levels (Figure 4) could be another reason behind the County's highest arsenic levels. Fluoride, on the other hand, is mainly found in water due to direct human activities [51]. Hydrofluoric acid (HF), another corrosive agent used in hydraulic fracturing, could be a reason behind the high F levels in Midland County and Martin County [52]. However, since hydraulic acid (HF) was not considered as a main hydraulic-fracturing substance used in all three counties, more information is necessary to get a better understanding about the levels of $\mathrm{F}$ in the groundwater of the study area.

Ector County, the county with the lowest hydraulic fracturing activity during 2016, showed the highest levels of $\mathrm{NO}_{3}$ (Figure 5), being more than four times higher than the other two counties. Commonly, agriculture is the main reason behind $\mathrm{NO}_{3}$ pollution [53], however, Ector County is also the county with the lowest agricultural activity of the three counties studied [54]. Therefore, it is safe to determine that nitrate groundwater pollution in Ector County is not oil and gas related, and that there is a pollution source other than agriculture behind $\mathrm{NO}_{3}$ pollution in Ector County. 
To have a better view of the relationship between depth and groundwater quality, levels of $\mathrm{Cl}^{-}$, $\mathrm{F}^{-}, \mathrm{CaCO}_{3}, \mathrm{NO}_{3}, \mathrm{TDS}$, and $\mathrm{pH}$ for the 14 wells analyzed in 2016 versus time were plotted (Figure 6). Complementary to this, a linear regression line was calculated and graphed, to know if the concentration of pollutants versus well depth had an increasing or decreasing character. Groundwater contamination by human activities is usually worse in shallow aquifers [55]. Consequently, deep aquifers should present lower levels of pollution. Contradictorily, the linear regression lines graphed on Figure 6 are increasing, which suggests a direct relationship between concentration of pollutant and depth. This relationship shows that deep aquifers are expected to present higher levels of contamination. Hence, human activities performed in the underground, like hydraulic fracturing, might be the reason behind found the results.
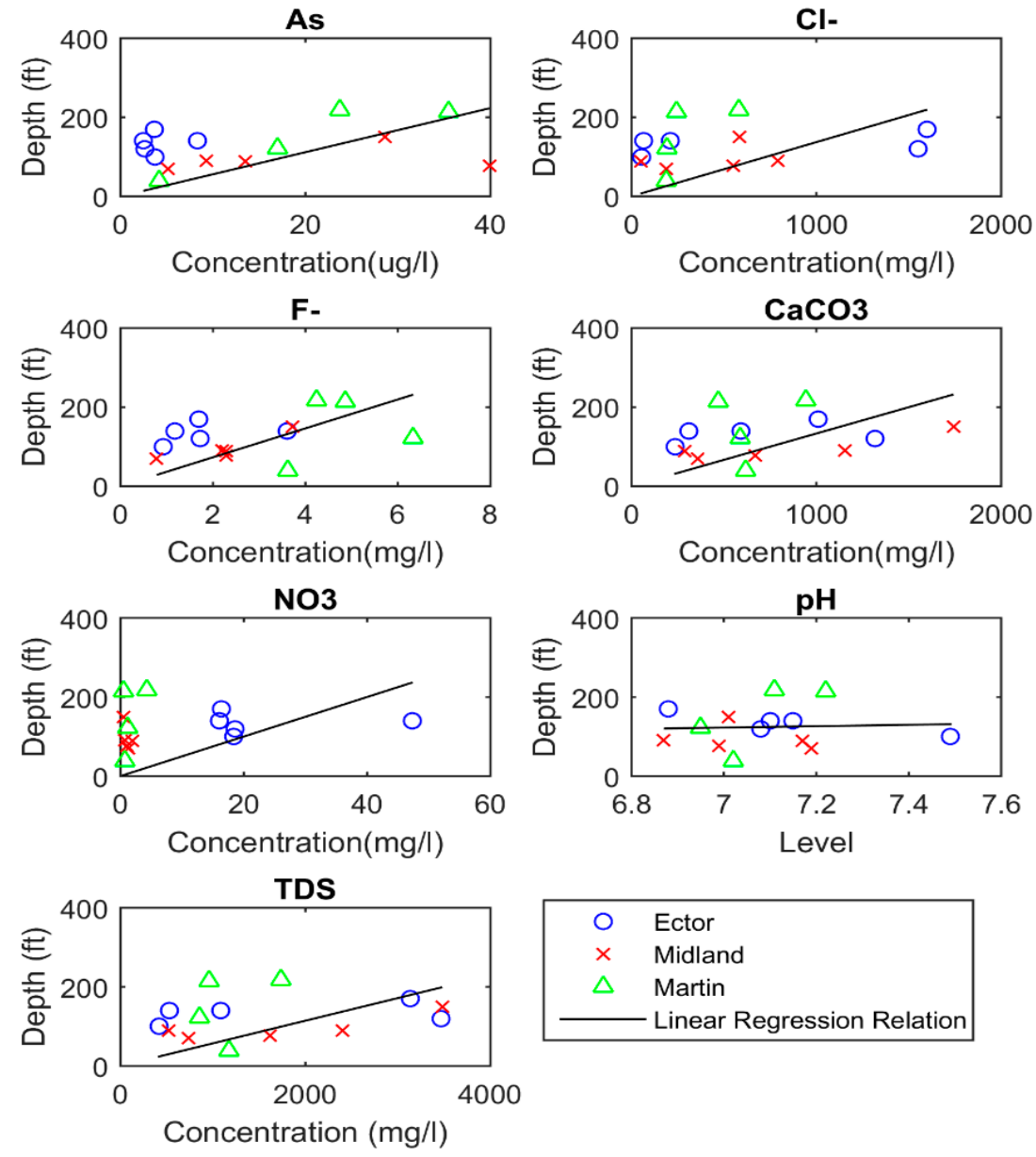

Figure 6. Groundwater quality parameters versus well depth in Ector County, Midland County, and Martin County.

In general, data of other years show relatively similar trends in Figure 6. Water depth can change over time due to changes in precipitation, streamflow amounts, and human-induced changes such as groundwater pumping and contamination [49]. The risk of contamination is greater in unconfined aquifers than confined aquifers because they usually are nearer to the land surface, and they lack an overlying confining layer impeding the movement of contaminants. Because groundwater moves slowly in the subsurface and many contaminants sorb to the sediments, restoration of a contaminated aquifer is difficult. In unconfined aquifers, contaminants from the soil or subsurface will directly affect the groundwater quality. The mutual influence of various chemical factors helps to evaluate hydrological processes responsible for changes in the groundwater quality. Groundwater tends to have much higher concentrations of most constituents than the surface waters do, and deep groundwater 
that has been in contact with the rock for a long time tends to have higher concentrations of the constituents than the shallow water.

The EPA primary water regulations list out all potential health effects from long-term consumption of the contaminants. As (Arsenic) can be present in water at the level of $10 \mathrm{ug} / \mathrm{L}$, and prolonged consumption of arsenic could cause damage of skin, circulatory system, and possibly increase risks for cancers. $\mathrm{F}^{-}$(Fluoride) can be present in water at the level of $2 \mathrm{mg} / \mathrm{L}$, and prolonged consumption can cause bone disease. $\mathrm{NO}_{3}$ (Nitrate) can be present in water at the level of $10 \mathrm{mg} / \mathrm{L}$, and prolonged consumption can cause infants to become sick and in some instance's death. $\mathrm{Cl}^{-}$(chloride) can be present in water at the level of $250 \mathrm{mg} / \mathrm{L}$, and can cause liver problems and increases the risk of cancer. Although regulated by $\mathrm{EPA}, \mathrm{CaCO}_{3}, \mathrm{pH}$, and TDS do not have any recorded effects on human health. However, these substance do affect the taste and appearance of drinking water [29]. Groundwater quality information was analyzed in order to have a better perspective of how levels of $\mathrm{As}, \mathrm{Cl}^{-}, \mathrm{F}^{-}$, $\mathrm{CaCO}_{3}, \mathrm{NO}_{3}$, TDS, and $\mathrm{pH}$ have been changing in the region overtime. While Table 5 shows the statistical mean of $\mathrm{Cl}^{-}, \mathrm{F}^{-}, \mathrm{CaCO}_{3}, \mathrm{NO}_{3}$, TDS, and $\mathrm{pH}$ per year, Figure 7 represents how they have been varying through the years, using a cubic hermit interpolation equation.

Table 5. Historical variations of groundwater quality parameters in Ector County, Midland County, and Martin County.

\begin{tabular}{|c|c|c|c|c|c|c|c|c|}
\hline & & $\begin{array}{c}\text { As } \\
\text { (ug/L) }\end{array}$ & $\begin{array}{c}\mathrm{Cl}^{-} \\
(\mathrm{mg} / \mathrm{L})\end{array}$ & $\begin{array}{c}\mathrm{F}^{-} \\
(\mathrm{mg} / \mathrm{L})\end{array}$ & $\begin{array}{c}\mathrm{CaCO}_{3} \\
(\mathrm{mg} / \mathrm{L})\end{array}$ & $\begin{array}{c}\mathrm{NO}_{3} \\
(\mathrm{mg} / \mathrm{L})\end{array}$ & $\mathrm{pH}$ & $\begin{array}{c}\text { TDS } \\
(\mathrm{mg} / \mathrm{L})\end{array}$ \\
\hline \multirow{6}{*}{ Ector } & 1999 & 2.80 & 917 & 1.34 & 881 & 20.01 & 7.01 & 2237 \\
\hline & 2003 & 5.95 & 408.67 & 2.30 & 614.67 & 37.16 & 7.15 & 1431.33 \\
\hline & 2007 & 7.50 & 995.50 & 1.25 & 1233.50 & 16.38 & 6.915 & 2834 \\
\hline & 2011 & 4.07 & 387.83 & 1.49 & 528 & 20.17 & 7.24 & 1208 \\
\hline & 2016 & 4.59 & 853.50 & 1.98 & 789.77 & 17.34 & 7.14 & 2026.09 \\
\hline & 2019 & 4.27 & 266.10 & 1.11 & 544.73 & 58.23 & 7.11 & 1032.07 \\
\hline \multirow{6}{*}{ Midland } & 1998 & 7.21 & 73.86 & 2.21 & 518 & 24.45 & 7.17 & 915 \\
\hline & 2003 & 7.63 & 91.20 & 2.26 & 366.67 & 18.27 & 7.20 & 747 \\
\hline & 2007 & 5.00 & 83.40 & 2.64 & 551.40 & 23.46 & 7.11 & 990.20 \\
\hline & 2010 & 5.76 & 68.18 & 2.29 & 493.40 & 25.40 & 6.96 & 868.60 \\
\hline & 2015 & 4.10 & 99.46 & 1.89 & 620 & 22.96 & 6.88 & 986.40 \\
\hline & 2019 & 4.35 & 63.10 & 2.06 & 521.61 & 22.29 & 6.85 & 846.74 \\
\hline \multirow{6}{*}{ Martin } & 1996 & 23.70 & 713.95 & 4.435 & 1083.50 & 57.21 & 7.02 & 2117.50 \\
\hline & 2000 & 22.66 & 239.70 & 3.39 & 445.33 & 32.43 & 7.28 & 1096.33 \\
\hline & 2004 & 24.02 & 301.20 & 4.55 & 514 & 34.73 & 7.22 & 1345.40 \\
\hline & 2008 & 21.53 & 320.48 & 4.32 & 580 & 43.01 & 7.21 & 1408.75 \\
\hline & 2012 & 20.15 & 332.05 & 4.18 & 596.75 & 46.96 & 7.32 & 1394.25 \\
\hline & 2016 & 21.13 & 339 & 4.24 & 676.72 & 17.77 & 7.12 & 1288.39 \\
\hline
\end{tabular}

Groundwater contamination is the most severe and controversial concern of hydraulic fracturing development. Oil and gas development in the Permian Basin has increased dramatically since 2010s. Some studies suggested that hydraulic fracturing could lead to additional contaminations [56-58]. Fluids may leak from faulty casing and cementing, thus contaminating shallow aquifers. The causes of shallow fluid leakage and transport include casing damage that provides leaking channel and faulty cementing which provide flowing space. The water samples from drinking wells less than $1 \mathrm{~km}$ from shale gas wells have higher methane concentration [56]. In addition, damaged casing and flawed cementing could lead to natural gas leaking into shallow groundwater. Flowback contains multiple contaminants with complex composition, mishandling of which would lead to contamination. Further research is required to find out how the hydraulic fracturing activities would affect the transport of naturally occurring hazardous substances. 

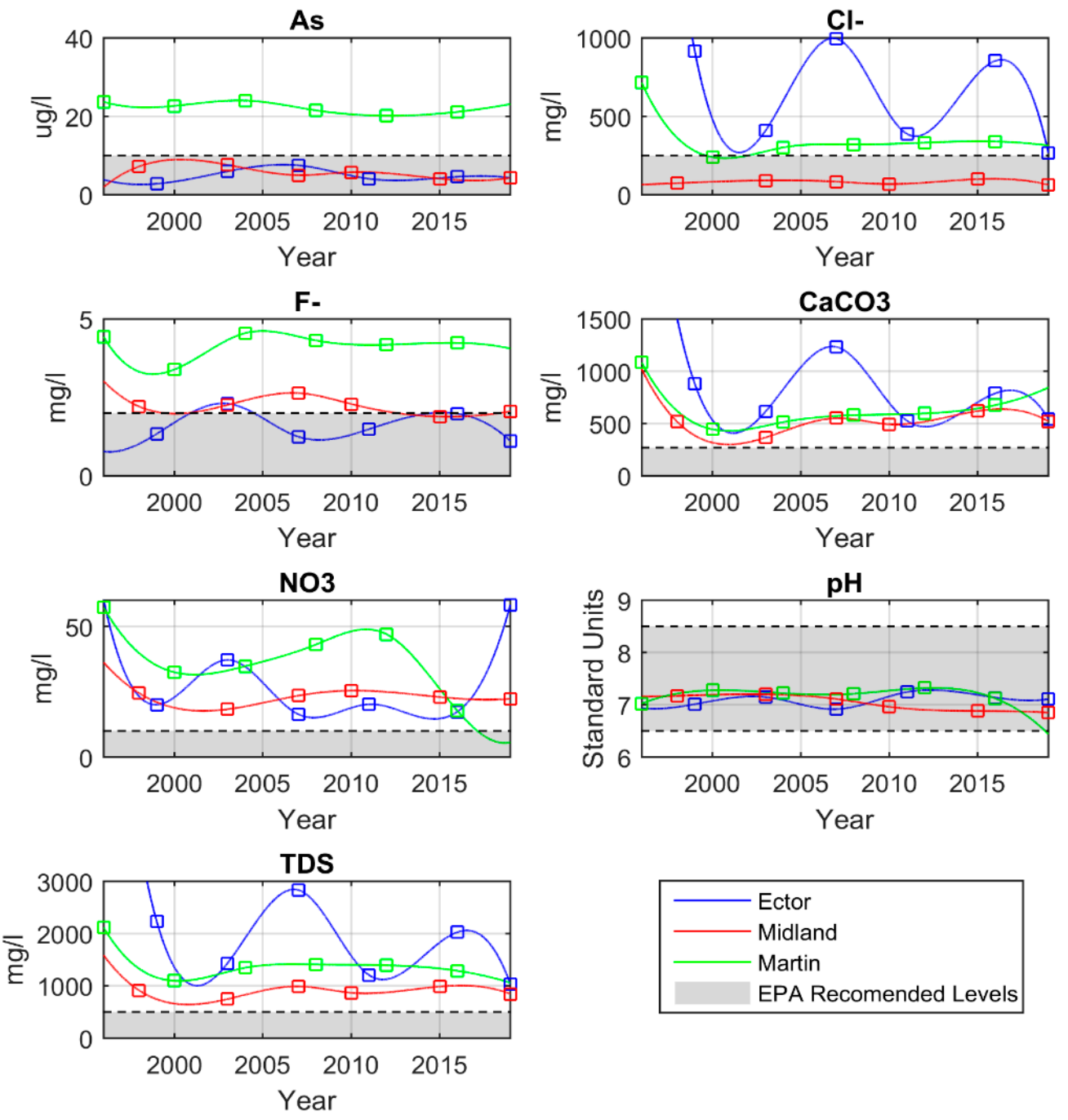

Figure 7. Historical analysises of groundwater quality parameters with Environmental Protection Agency (EPA) levels in the Ector County, Midland County, and Martin County.

\section{Conclusions}

This study evaluated the relationship between groundwater contamination and hydraulic fracturing. Based on the data collected and analyzed, with a higher concentration of substances different to sand and water in the hydraulic fracturing used (HCL, petroleum distillates, and guar gum), Midland County presented the overall highest levels of groundwater contamination. Martin County presented the second highest levels on contamination, proving that the number of hydraulic fracturing wells was an important aspect to take into consideration for the purposes of this research. It was possible to find a relationship between groundwater contamination and oil and gas activities. The parameters indicative of the groundwater quality and their correspondent high levels triggered by hydraulic fracturing activities were studied. It was also possible to determine that higher contamination levels are expected to occur in deep aquifers. This depth-contamination correspondence also supports the idea of human activities, underground development, and polluting groundwater reservoirs.

Statistical methods proved to be helpful in analyzing datasets with information of different sizes. However, a more extensive dataset for groundwater wells in Midland, Ector, and Martin counties will be crucial for future studies. More information about groundwater quality in these three counties can give more definitive results about the evident relationship between hydraulic fracturing and groundwater contamination found in this study. This study contributes to the understanding of 
the response to groundwater contaminations associated with oil and gas production causes in the study area. Therefore, this research can provide significant information for the management of water resources in the Permian Basin and the response to development in hydraulic fracturing. Our study set a basis for the study of the relationship between hydraulic fracturing and groundwater quality, thus corrective and preventive actions can be taken in future once this relationship is fully understood.

Author Contributions: J.R. collected detailed information on the study area, calculated the hydraulic fracturing and groundwater quality level, and analyzed the results with conclusions. J.H. designed the structure, developed the arguments, and contributed for the overall paper. K.H.K. contribution-data curation, validation, writing-review\&edit. All authors have read and agreed to the published version of the manuscript.

Funding: This work was supported by a Rising STAR (Science and Technology Acquisition and Retention) Program from the University of Texas System.

Conflicts of Interest: The authors declare no conflict of interest.

\section{References}

1. Fabryka-Martin, J. Hydrology: The Study of Water and Water Problems: A Challenge for Today and Tomorrow; Universities Council on Water Resources: Carbondale, IL, USA, 1983.

2. UTSA Economic Impact of Oil and Gas Activities in the West Texas Energy Consortium Study Region; University of Texas San Antonio: San Antonio, TX, USA, 2012.

3. U.S. Department of Energy. Permian Basin Wolfcamp Shale Play; U.S. Department of Energy: Washington, DC, USA, 2018.

4. Clifford, K. Land Rush in Permian Basin, Where Oil Is Stacked Like a Layer Cake. 2017. Available online: https://www.nytimes.com/2017/01/17/business/energy-environment/exxon-mobil-permian-basinoil.html (accessed on 24 May 2019).

5. Merrill, T.W.; Schizer, D.M. The Shale Oil and Gas Revolution, Hydraulic Fracturing, and Water Contamination: A Regulatory Strategy. Minn. Law Rev. 2013, 98, 145. [CrossRef]

6. William, N.; Jasinski, R.; Nelson, E. Hydraulic Fracturing Process and Compositions. U.S. Patent 5,551,516, 3 September 1995.

7. Montcoudiol, N.; Isherwood, C.; Gunning, A.; Kelly, T.; Younger, P.L. Shale gas impacts on groundwater resources: Understanding the behavior of a shallow aquifer around a fracking site in Poland. Proc. Energy Procedia 2017, 125, 106-115. [CrossRef]

8. Mehany, M.S.H.M.; Kumar, S. Analyzing the feasibility of fracking in the U.S. using macro level life cycle cost analysis and assessment approaches-A foundational study. Sustain. Prod. Consum. 2019, 20, 375-388. [CrossRef]

9. Long, S.C. Direct and indirect challenges for water quality from the hydraulic fracturing industry. J. Am. Water Works Assoc. 2014, 106, 53-57. [CrossRef]

10. EPA Hydraulic Fracturing for Oil and Gas: Impacts from the Hydraulic Fracturing Water Cycle on Drinking Water Resources in the United States; US EPA: Washington, DC, USA, 2016.

11. Marcus, D.L.; Bonds, C. Results of the reactant sand-fracking pilot test and implications for the in situ remediation of chlorinated VOCs and metals in deep and fractured bedrock aquifers. J. Hazard. Mater. 1999, 68, 125-153. [CrossRef]

12. Hildenbrand, Z.L.; Carlton, D.D.; Fontenot, B.E.; Meik, J.M.; Walton, J.L.; Thacker, J.B.; Korlie, S.; Shelor, C.P.; Kadjo, A.F.; Clark, A.; et al. Temporal variation in groundwater quality in the Permian Basin of Texas, a region of increasing unconventional oil and gas development. Sci. Total Environ. 2016, 562, 906-913. [CrossRef]

13. Backstrom, J. Groundwater Regulation and Hyarulic Fracturing: Reporting Water In the Permain. STRATA Working Paper. 2018, pp. 1-34. Available online: https://www.strata.org/pdf/2018/groundwater-regulations. pdf (accessed on 11 October 2019).

14. UNSD. United Nations Conference on Environment and Development; UNSD: New Yokr, NY, USA, 1992.

15. USDA. Soil Survey of Midland County, Texas; UNSD: New Yokr, NY, USA, 1973.

16. Ashworth, J.; Christian, P. Evaluation of Ground-Water Resources In Parts of Midland, Reagan, and Upton Counties, Texas; Texas Water Development Board: Austin, TX, USA, 1989. 
17. Simmers, I.; Hendrickx, J.M.H.; Kruseman, G.P.; Rushton, K.R. Recharge of Phreatic Aquifers in (Semi-) Arid Areas; Balkema, A.A., Ed.; IAH Publication: Hannover, Germany, 1997; ISBN 9789054106944.

18. George, P.; Mace, R.; Petrossian, R. Aquifers of Texas; Texas Water Development Board: Austin, TX, USA, 2011.

19. U.S. Census Bureau. Population Estimates; U.S. Census Bureau: Suitland, MD, USA, 2008.

20. U.S. Census Bureau. Population Estimates; U.S. Census Bureau: Suitland, MD, USA, 2016.

21. FracFocus. Hydraulic Fracturing Data 2016. Available online: http://fracfocus.org/ (accessed on 15 October 2019).

22. Elliott, E.G.; Ettinger, A.S.; Leaderer, B.P.; Bracken, M.B.; Deziel, N.C. A systematic evaluation of chemicals in hydraulic-fracturing fluids and wastewater for reproductive and developmental toxicity. J. Expo. Sci. Environ. Epidemiol. 2017, 27, 90-99. [CrossRef]

23. Frac Focus. Chemical Disclosure Registry. Available online: http://fracfocus.org/ (accessed on 28 November 2019).

24. TWDB. Groundwater Data; Texas Water Development Board: Austin, TX, USA, 2016.

25. Cumming, G. Understanding The New Statistics: Effect Sizes, Confidence Intervals, and Meta-Analysis; Multivariate Applications Series; Routledge: Abingdon-on-Thames, UK, 2011; ISBN 041587968X.

26. Rozell, D.J.; Reaven, S.J. Water Pollution Risk Associated with Natural Gas Extraction from the Marcellus Shale. Risk Anal. 2012, 32, 1382-1393. [CrossRef]

27. Michalski, R.; Ficek, A. Environmental pollution by chemical substances used in the shale gas extraction-A review. Desalin. Water Treat. 2016, 57, 1336-1343. [CrossRef]

28. Vengosh, A.; Jackson, R.B.; Warner, N.; Darrah, T.H.; Kondash, A. A critical review of the risks to water resources from unconventional shale gas development and hydraulic fracturing in the United States. Environ. Sci. Technol. 2014, 48, 8334-8348. [CrossRef]

29. US EPA. National Primary Drinking Water Regulations; United States Environmental Protection Agency: Washington, DC, USA, 2017.

30. UALR. One-Way Analysis of Variance (ANOVA) Example Problem; UALR: Little Rock, AR, USA, 2014.

31. Vasudev, R. How Are Logistic Regression and Ordinary Least Squares Regression (Linear Regression) Related? Why the "Regression" in Logistic? Available online: https://towardsdatascience.com/how-arelogistic-regression-ordinary-least-squares-regression-related-1deab32d79f5 (accessed on 28 November 2019).

32. Rodriguez, J.; Heo, J.; Park, J.; Lee, S.S.; Miranda, K. Inorganic Pollutants in the Water of Midland and Odessa, Permian Basin, West Texas. Air Soil Water Res. 2019, 12, 1-7. [CrossRef]

33. Kaya, E. Spline Interpolation Techniques. J. Tech. Sci. Technol. 2017, 47-52.

34. Ahlfeld, D.P.; Pinder, G.F. Solving Stochastic Groundwater Problems using Sensitivity Theory and Hermite Interpolating Polynomials. In Developments in Water Science; Elsevier: Amsterdam, The Netherlands, 1988; pp. 179-184.

35. Thompson, M.; Desjardins, P.; Pickering, J.; Driskill, B. An integrated view of the petrology, sedimentology, and sequence stratigraphy of the Wolfcamp Formation Delaware basin Texas. In Proceedings of the SPE/AAPG/SEG Unconventional Resources Technology Conference 2018, Houston, TX, USA, 23-25 July 2018.

36. Detrow, S. Hydrochloric Acid's Role in the Fracking Process. 6 July 2012. Available online: https://stateimpact.npr. org/pennsylvania/2012/07/06/hydrochloric-acids-role-in-the-fracking-process/ (accessed on 15 October 2019).

37. US EPA. Hydrochloric Acid (Hydrogen Chloride); US EPA: Wahsington, DC, USA, 2000.

38. Jain, N.; Garg, K.; Karmakar, N.C.; Palei, S.K. Guar Gum in Hydraulic Fracturing in Indian Shale Mines. In Proceedings of the Present technology and Safety Scenario in Mining and Allied Industries, Varanasi, India, 25-27 February 2013.

39. Lagier, F.; Cartier, A.; Somer, J.; Dolovich, J.; Malo, J.L. Occupational asthma caused by guar gum. J. Allergy Clin. Immunol. 1990, 85, 785-790. [CrossRef]

40. Denger, D.L. Hydraulic fracturing fluid considerations in Marcellus Shale completions. In Proceedings of the EPA Hydraulic Fracturing Tech Workshop, Washington, DC, USA, 24-25 February 2011; Available online: https://www.epa.gov/hfstudy/hydraulic-fracturing-fluid-considerations-marcellus-shalecompletions-feb-24-25-2011 (accessed on 11 October 2019).

41. Horwitt, D. Drilling around the law. Environmental Working Group. 2010. Available online: https: //www.ewg.org/sites/default/files/report/EWG-2009drillingaroundthelaw.pdf (accessed on 11 October 2019).

42. US EPA. Safe Drinking Water Act (SDWA); US EPA: Kansas City, KS, USA, 2017.

43. WHO (World Health Organization). Arsenic in Drinking Water; WHO: Geneva, Switzerland, 2011. 
44. Angeles Martínez-Mier, E. Fluoride: Its Metabolism, Toxicity, and Role in Dental Health. J. Evid. -Based Complement. Altern. Med. 2012, 17, 28-32. [CrossRef]

45. Rafiqul Islam, M. A Study on the TDS Level of Drinking Mineral Water in Bangladesh. Am. J. Appl. Chem. 2016, 4, 164. [CrossRef]

46. Kendrick, J.S.; Williamson, D.F.; Parker, R.A.; Kendrick, J.S. The box plot: A simple visual method to interpret data. Ann Intern Med 110: 916 The Box Plot: A Simple Visual Method to Interpret Data. Acad. Clin. 1989, 10, 916-921.

47. Reddi, B.A.J. Why is saline so acidic (and does it really matter?). Int. J. Med. Sci. 2013, 10, 747-750. [CrossRef]

48. Total Dissolved Solid-An Overview. ScienceDirect Topics. Available online: https://www.sciencedirect. com/topics/engineering/total-dissolved-solid (accessed on 21 November 2019).

49. Fontenot, B.E.; Hunt, L.R.; Hildenbrand, Z.L.; Carlton, D.D., Jr.; Oka, H.; Walton, J.L.; Hopkins, D.; Osorio, A.; Bjorndal, B.; Hu, Q.H.; et al. An Evaluation of Water Quality in Private Drinking Water Wells Near Natural Gas Extraction Sites in the Barnett Shale Formation. Environ. Sci. Technol. 2013, 47, 10032-10040. [CrossRef]

50. Healy, D. Hydraulic Fracturing or "Fracking": A Short Summary of Current Knowledge and Potential Environmental Impacts; Environmental Protection Agency: Loch Garman, Ireland, 2012.

51. Peckham, S.; Awofeso, N. Water fluoridation: A critical review of the physiological effects of ingested fluoride as a public health intervention. Sci. World J. 2014, 2014, 1-10. [CrossRef]

52. Mall, A. New Report on Fracking Chemicals, Including One That Is a Potential "Chemical Terrorism Agent". NRDC. Available online: https://www.nrdc.org/experts/amy-mall/new-report-fracking-chemicals-includingone-potential-chemical-terrorism-agent (accessed on 21 November 2019).

53. Oenema, O.; Boers, P.C.M.; Van Eerdt, M.M.; Fraters, B.; Van Der Meer, H.G.; Roest, C.W.J.; Schröder, J.J.; Willems, W.J. Leaching of nitrate from agriculture to groundwater: The effect of policies and measures in The Netherlands. Proc. Environ. Pollut. 1998, 102, 471-478. [CrossRef]

54. NASS; USDA. Cesus of Agriculture-Ector County Texas; USDA: Washington, DC, USA, 2012.

55. Groundwater Pollution-An Overview. ScienceDirect Topics. Available online: https://www.sciencedirect. com/topics/earth-and-planetary-sciences/groundwater-pollution (accessed on 21 November 2019).

56. Jackson, R.B.; Vengosh, A.; Darrah, T.H.; Warner, N.R.; Down, A.; Poreda, R.J.; Karr, J.D. Increased stray gas abundance in a subset of drinking water wells near Marcellus shale gas extraction. Proc. Natl. Acad. Sci. USA 2013, 110, 11250-11255. [CrossRef] [PubMed]

57. Spellman, F.R. Environmental Impacts of Hydraulic Fracturing; Taylor and Francis Group: Abingdon, UK, 2013; p. 75.

58. Zhang, D.; Yang, T. Environmental impacts of hydraulic fracturing in shale gas development in the United States. Pet. Explor. Dev. 2015, 42, 876-883. [CrossRef] 